\title{
Model Of Tourism Developmentin Lembata Regency: Community-Based Tourism Approach
}

\author{
Hamzah Nazarudin ${ }^{1}$, Septia Sakalini Dioh ${ }^{1}$ \\ (alhimza@gmail.com, septiasakalinidioh@gmail.com) \\ Politeknik Negeri Kupang ${ }^{1}$
}

\begin{abstract}
This paper aimed at identifying the tourism potentials that can be developed into community-based tourism, identifying the factors inhibiting community-based tourism in Lembata, and creating effective models for the development of Community based tourism in Lembata. The research design used in the current research was descriptive qualitative. The procedure was based on research and development principles, that is by applying Board and Gall theory. the adaptation and modifications stages are as follows, collecting data in the field, analyzing the data,formulating a model of development of community-based tourism in Lembata. The techniques of collecting data were observation, interviews, and documentation. The techniques of analysis data were data reduction, data presentation, and conclusion. The results showed that tourism potential that can be developed into community-based tourism in the Lembata include, natural tourism, marine tourism, culture tourism. The factors inhibiting community-based tourism in Lembata were Infrastructure does not support, the community participation is still low in the developing tourism in Lembata, Output of the research is designing development model of the community-based tourism as a strategy for the local economic empowerment in Lembata.
\end{abstract}

Keywords: Tourism Development, CBT Approach, Lembata Regency

\section{Introduction}

Community-Based Tourism puts attention to the sustainable social and cultural environment. This model of tourism is managed and owned by the community for the community, to help tourists increasing their awareness and learn about the community and local people's way of life.

Community-based tourism is very different from mass tourism.According to Pinel [1], Community-based tourism is a tourism development model that assumed to be running from a level of awarenessto the level of the community needs. It is as an effort to build tourism that is more beneficial to the needs, initiatives, and opportunities of local communities.It is more related to the impact of tourism on society and environmental resources.

Previous researches on community-based tourism have ever been carried out. Interested in community participation in the world of tourism was rooted in America in the early 1970s. Gun [2] campaigned the use of a joint forum attended by the constituent community and tourism designers. Next, Murphy [3] argued that tourism products are locally articulated and consumed. Tourism products and consumers must be visible to residents who are often very aware of the impact of tourism. Industry circles must also involve the local 
community in decision making because local people must bear the cumulative impact of tourism development [3].

Gets and Jamal [4] Criticizing Murphy's model because they have to offer a blueprint to implement it in real form. Murphy's concept in its implementation has still got problems. Public participation is seen as a tool to maintain the integrity and capability of tourism products, Gunn [2]. When public participation arises, tourism destination planning remains commercially focused and involves very small communities. This tourism planning model aims to focus more on efforts to preserve the power of tourism, and in reality, it is more business-oriented with an economically oriented approach, Bahaire and Elliot-white [5]

Gets and Jamal [4] develop a theoretical foundation for community involvement in tourism planning and development. They analyze the character and purpose of the collaboration model and define collaboration as a process of joint decision making between stakeholders, that is to solve problems or manage issues related to tourism Gets and Jamal [4]. The collaboration process includes(1) the problem that setting by identifying key stakeholders and problems, (2) direction setting with various collaborations to inspire general goals, structure, and implementation, (3) Institutionalization.

The role of government in the development of community-based tourism is very important to strengthen the communities around tourist destinations, Beeton [6]. The government has a role to ensure that people have access. Opportunities and strengths in the development of tourism through regulations are intended to regulate certain activities in the area. The government can make certain rules that can dictate other parties to support and implement government policies in community empowerment. Regulation itself is a tool for the government in ensuring tourism stakeholders. It continues to behave in the corridors of tourism policies following conditions set by the government, Pitana and Gayatri [7]

Related to this research, the district government of Lembata places the tourism sector as a promising sector to empower the local economy in Lembata district. Various kinds of uniqueness and tourist attraction inLembataregency has the potential to increase the country's foreign exchange and has great prospects in the future. One tourism icon that has been widely known by tourists, both local and foreign tourists, are whaling cultures (hunting whale traditionally) in Lamalera village, Lembata district. To optimize tourism potential in Lembata Regency, the role of local government is needed. Government has to manage and market the tourism products so it will become a potential source for the region. Furthermore, the government has to issue policy breakthroughs that can embrace stakeholders for the sustainability of tourism through community empowerment.

\section{Research Method}

The method used in the current research was descriptive qualitative. The procedure was based on research and development principles. The principles were proposed by Board and Gall. The adaptation and modifications stages were as follows: Collecting data in the field, analyzing the data, and formulating a model of development of community-based tourism in Lembata. The techniques of collecting data were observation, interviews, documentation. The research was located in Lembata regency. Researchers acted as an active instrument in order to collect data in the field. Source of information in this study was the staff of the department of culture and tourism, while other sources of information are tourist, community leaders, and community living near attractions in Lembata. The techniques of Analysis data were data reduction, data presentation, discussion, and conclusion. 


\section{Results and Discussion \\ Identifying the tourism potentials that can be developed into community-based tourism}

Lembata is a district in the province of NTT. It is located between East Flores Regency and Alor Regency. The location is bordered by the Flores Sea to the north and the Sawu Sea to the south. Whereas in the west, it is bordered by Boleng Strait and Lamakera Strait. In the east, it is bordered by the Strait of Alor.Lembata Regency, with Lewoleba as its capital city, has got many excellent tourist attractions.It has diverse tourism potential, such as nature tourism, marine tourism, cultural tourism, and interesting archeology.Undeniable, if the tourism potential is developed, it can be a supporting sector for the regional economy to improve the welfare of the people in Lembata district.

Tourism potential of Lembata Regency, as explained, is more emphasized on conventional tourism. The government of Lembata Regency seeks alternative tourism development that involves the community. The types of tourism that will be developed into Community-Based Tourism in Lembata Regency are presented as follows:

- Awelolong White Sand Island

- Maria's Cave at Lewoleba

- Waijarang White Sand Recreation Beach

- Sabu Tobu Hot Spring,Adum hot spring and Labalimut hot springs

- Karun Watuwawer Natural Gas Source

- Tanah Treket Recreational Beach

- Traditional whaling culture in Lamalera Village

- Traditional house and Jontona nut Party ritual

- Mingar White Sand Beach

- Lewolein Beach

- Nubi Beach in Lusiduawutun.

- Atawuwur Waterfall

- White sand beach bean

- White Sand Beach Wowong

- King Saguwowo'sGrave in Kalikur Village

\section{Identifying the factors inhibiting community-based tourism in Lembata}

The implementation of CBT in Lembata Regency meets several obstacles, namely the insufficient source of funds, lack of human resources in the field of tourism development. Lack of community preparedness in responding to the importance of tourism developmenthas also been an obstacle. It is because the majority of people who live as fishermen tend to be apathetic and unconscious with the potential. Therefore, the innovation and creation from the relevant community parties, as well as the development of tourism,can not be optimal. In the other side, supports from the private sector is still low. The number of investors who are willing to help developing CBT is low.

The role of government is needed as the main motivator in over coming these problems. The community and investors as the main target continue to be encouraged to be involved in the development of tourism in Lembata Regency, The district government, through the Departementof Culture, Tourism, Youth and Sports (Dinas PPO), Lembata District, has made efforts to encourage the involvement of investors and the community in developing the tourism sector. It is a superior sector through Lembata district tourism promotion.

The efforts of the Lembata district government, in synergizing stakeholders, experience problems because of the low participation of public and investors. People around 
the distric are not interested as well as are not motivated in developing tourism in Lembata Regency. The role of the community in developing tourism potential is big and needs to be balanced with the role of the government and the private sector. However, in the management and development of tourism in Lembata Regency, it is still fully controlled by the government that is by relying on incentives and initiatives from the local government. High tourism potential in the district of Lembata should be optimized, not only seen as a potential for regional income but as an effort to preserve the culture of the region that has begun to be abandoned.

\section{The model of Community-based tourism development in Lembata}

The development of CBT in Lembata Regency will be useful in creating employment opportunities, reducing poverty levels,preserving the environment as well as local culture. This will be able to empower the community's economy. The CBT development model, as a strategy for the economic empowerment of local communities,is formulated based on consideration of the potential and existing problems.The CBT Development Model will succeed if all components are available and have got support from stakeholders. The support is in the form of partnership through programs, regulations, venture capital, community involvement, and infrastructure. The support is in the form of partisanship through programs and regulations, venture capital, partnerships, as well as community involvement, and infrastructure.

Adimihardja in Sunaryo [8], defines community empowerment as a process which does not only develop the economic potential of a powerless community but must also strive to increase dignity,self-confidence and self-esteem and maintenance of local cultural values. Community empowerment is intended as an effort to strengthen helpless communities, usually, those who belong to marginal communities. The community-based tourism model in this study refers to the model developed by Sunaryo [8]. It is shown as follows :

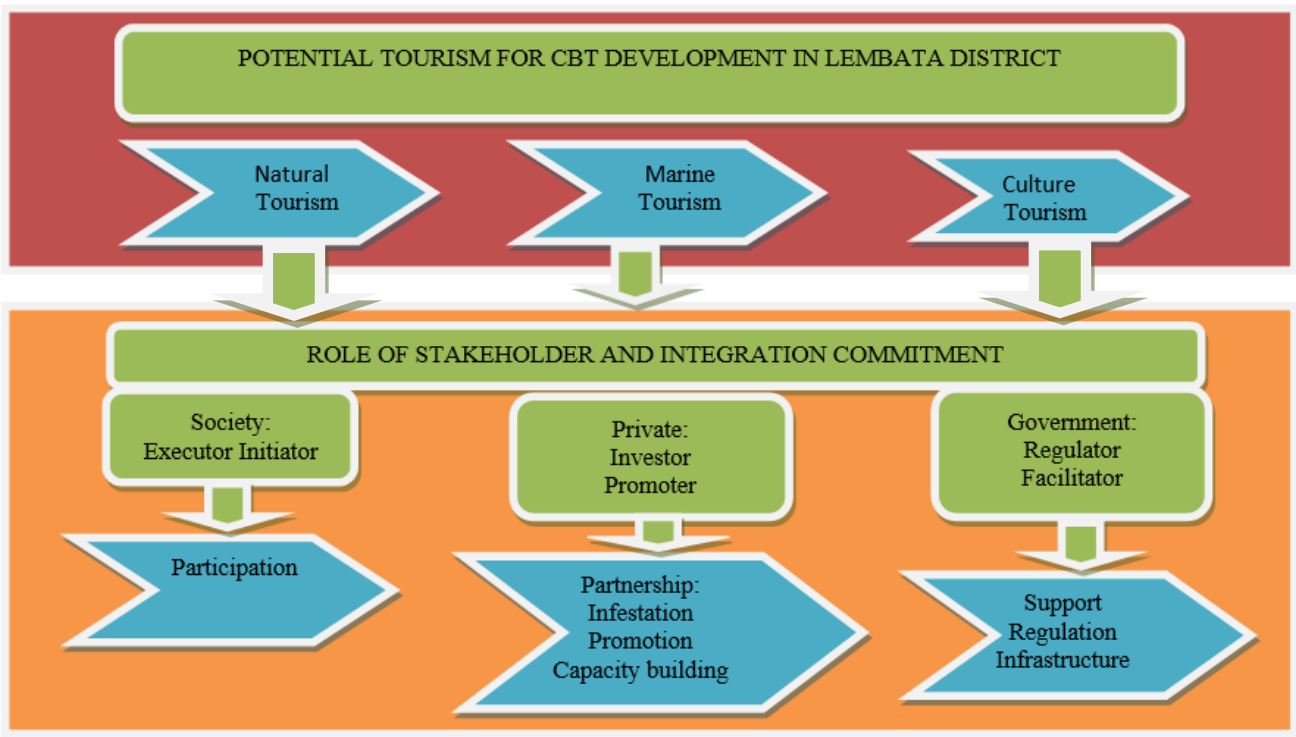

Figure 1 : Model of Tourism Development in Lembata Regency 


\section{Conclusion}

Tourism potential that can be developed as a CBT model in Lembata Regency is nature tourism, marine tourism, and cultural tourism. This type of tourism will involve community participation. The participation itself must be shown directly (as the actors) and indirectly (as supporters). The above tourism activities can also build an entrepreneurial spirit and community creativity, thus affecting the welfare of the people Efforts in developing tourism of Lembata Regency.

Efforts to develop tourism in Lembata Regency are carried out through Tourism development program, Development of tourism marketing, namely the development of tourism partnershipsand the development of CBT itself. There are several obstacles encountered,namelythe (1) the insufficient source of funds,(2) lack of human resources in the field of tourism development,and (3) the unpreparedness of the community in responding to the importance of tourism development. Consequently, innovation and creations from parties related to tourism development cannot be optimal.

The development of CBT in Lembata Regency will be useful in creating employment opportunities, reducing poverty levels, preserving the environment as well as local culture. It will be able to empower the community's economy.The CBT development model itself is a strategy for the economic empowerment of local communities in Lembata Regency.The CBT development model, as a strategy for the economic empowerment of local communities in Lembata Regency,was formulated based on consideration of the potential and existing problems. The CBT Development Model will succeed if all components are available and have support from stakeholders. The support is in the form of partisanship through programs and regulations, venture capital, partnerships, as well as community involvement, and infrastructure.

\section{References}

[1] Pinel, D. 1998. A community-based tourism planning process model: Kyuquot Sound Area, British Columbia. Master of Science Thesis, University of Guelph.

[2] Gunn, C. A. 1988 Tourism Planning. New York NY: Taylor \& Franci

[3] Murphy, P.E. (1985) Tourism: A community approach. New York and London: Methuen.

[4] Jamal, T.B. and Getz, D. (1999) Community roundtables for tourism-related conflicts: The dialectics of consensus and process structures. Journal of Sustainable Tourism 7 (3-4), 290-313).

[5] Bahaire and Elliot-white (1999) Community Participation in tourism planning and development in the historic city of tork, England

[6] Beeton, S. (2006). Community development through tourism. In: Landlink Press, Austra

[7] Pitana, I Gde \& Putu G Gayatri. 2005. Sociology of Tourism. Andi Pres: Yogyakarta

[8] Sunaryo. Bambang. 2013. Tourism Destination Development Policy: The Concept and Application in Indonesia. Gava media. Yogyakarta. 